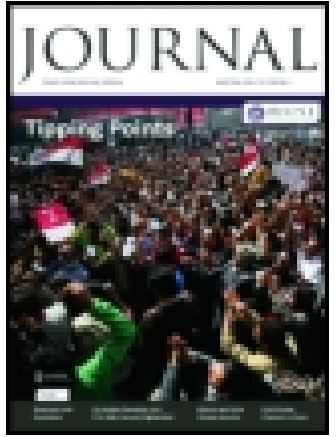

Royal United Services Institution. Journal

\title{
Use of Ski, and Training of British Soldiers for Duties on Snow-Clad Frontiers
}

\section{Captain Howard V. Knox}

To cite this article: Captain Howard V. Knox (1910) Use of Ski, and Training of British Soldiers for Duties on Snow-Clad Frontiers, Royal United Services Institution. Journal, 54:384, 149-165, DOI: $10.1080 / 03071841009425472$

To link to this article: http://dx.doi.org/10.1080/03071841009425472

册 Published online: 12 Nov 2009.

Submit your article to this journal $₫$

Џll Article views: 5

Q View related articles ๘ 


\title{
USE OF SKI, AND TRAINING OF BRITISH SOLDIERS FOR DUTIES ON SNOW-CLAD FRONTIERS.
}

\author{
By Captain HOWARD V. KNOX.
}

\author{
On Wednesday, igth November, Igog. \\ Brig.-General H. H. WILSON, C.B., D.S.O., p.s.c., \\ Commandant, Staff College, in the Chair.
}

TḦOUGH a knowledge of ski-ing is probably not so vital to our military interests as it is in the case of the central European Powers, with their mountain frontiers, yet the subject hardly merits the neglect which it still encounters in this country. For, after all; we have a mountain frontier in India; and instances are not wanting, as I hope to show later, where ski would undoubtedly have been of the greatest service in Indian border warfare. Unfortunately, I have never myself been in the Himalayas; but doubtless in the subsequent discussion light will be thrown on the question of the general suitability of the Himalayan region for purposes of ski-ing. In fact, the chief purpose of this paper is to direct attention to this very practical and important question, which has as yet hardly been investigated at all." But even apart from the suitability of ski to our own needs, it seems worth while, in the interests of military thcory, to. understand the nature of ski and the way in which they may subserve military ends. For now that the great military Powers have all taken the matter up seriously, ${ }^{1}$ it seems certain that the use of ski must in future be an important factor in any winter campaigning on the Continent. And, finally, it is neither safe nor dignified to assume that the interest of the British soldier in future European conflicts must necessarily be of a purely academic character.

Twenty years' ago the word "ski" would probably have evoked no suitable mental image for many of the people in this room-including the lecturer. The appearance in 1890 of Nansen's account of his crossing of Greenland on ski may be taken as the event, which brought these Dark Ages to a close.

$\because 1$ Ski have been definitely introduced into the armies of Norway. Sreden, Russia, France; Germany, Switzerland, Italy, and Austria. Hungary.: They have been experimented with in the armies of the United States and Japan: 
But it is only within the last ten years or so that ski-ing has been extensively pursued as a sport outside Scandinavia. And even in these days, when its attractions are pictorially proclaimed in our. railway stations, there is room for doubt as to whether many of the uninitiated have an adequate understanding of what ski-ing really is.. The advantages of ski-ing are sufficiently great to free us from the temptation of exaggerating them, and we need not be afraid of admitting at the outset that even ski-ing has its limits. A short time ago, in one of our inustrated monthly magazines, there appeared a thrilling tale of a ski-runner who baulked pursuing wolves of their prey by taking a flying leap over a stockade of exceeding height. The writer had evidently heard vaguely of the wonderful jumping, feats, executed by Norwegian skiers, 'and had 'not grasped the fact that ski-jumping takes place down a slope. The high jump has not as yet figured as an event at any recognised ski meeting.

It is, of course, quite foreign to the purpose of the present lecture to treat of ski-ing simply from the point of view of sport. Nor do I propose to go into the technique of ski-ing. . For full treatment of this side of the subject, and for advice as to choosing ski, etc.; I may refer my hearers to the excellent little manual "Ski Running," edited by. Mr. E. C. Richárdson (2nd edition ig07). Historically speaking, it is to be observed that the development of ski-ing as a sport pursued for its own sake is quite recent. It is purely an outgrowth from the use of ski in the every-day life of the inhabitants of northern Eurasia, as a means of communication and for the pursuit of game in winter. Ski were undoubtedly devised in the first instance as a practical response to environmental conditions, though their actual genesis, in the well-worn phrase of the baffled historian, is " lost in the mists of antiquity." The chapter on "Ski and Skilöbning," in Nansen's ." Crossing of Greenland," should be referred to by those interested in the historical side of our subject. ${ }^{1}$. Here it is merely alluded to in order to dispel any prejudice that might arise from the mistaken idea that the utilisation of ski for practical purposes is only an afterthought: In reality, it is ski-ing as an amusement which was the afterthought.

It is, however, permissible to point out in passing, that, taken simply as a sport, ski-ing is unsurpassed as a means of developing all-round physical fitness, including therein nerve, resourcefulness, and eye for country. Of it Nansen says :- "I know no form of sport which so evenly develops the muscles, which renders the body so strong and elastic, which teaches so well the qualities of dexterity and resource, which in an equal degree calls for decision and resolution, and which gives the same vigour and exhilaration to mind and body alike. . . . . Where will one find more freedom and excitement than when one

1See also "Die Schi-Literatur," by Henry Hoek (Gustav Lammers, Münich and Vienna, 1908), a very useful bibliography in pamphlet form: 
glides swiftly down the hillside through the trees, one's cheek brushed by the sharp cold air and frosted pine branches, and one's eye, brain, and muscles alert and prepared to meet every unknown obstacle and danger which the next instant may throw in one's path ?.. . . There is something in the whole which develops soul and not body alone, and the sport is perhaps of far greater national importance than is generally supposed" ("Crossing of Greenland," I., 84).

The military value of ski must obviously be determined by their nature as aids to locomotion. "It is therefore necessary to state precisely what their utility in this respect is. Though, as a matter 'of terminology, it is usual to distinguish ski from "snowshoes," the ski is essentially a long wooden snow-shoe with turned-up poirts. The design of the blade is slightly different, in different models, but for all-round purposes thie "Telemark", type is generally. allowed to be the best. There is, however, considerable diversity of opinion as to the best "binding," or means of attaching the ski to the foot; but we need not go into controversial matters. 'The ideal binding would be (inter alia) both light and strong, and would also be easy to adjust. It has not yet been discovered; : but each individual skier believes he possesses the next best thing to it. Whatever its other merits or defects, a binding, to be worth anything at all, must be such as to secure lateral rigidity-which is essential to control-combined with freedom to raise the heel of the boot well off the blade-which is no less essential to the proper management of the instrument.

The ski shares with other forms of snow-shoe the advantage of enabling the wearer to walk on the surface of deep snow, where a man without: such appliances would find progress exccssively laborious or even impossible. Its special advantage over all ordinary snow-shoes is, that it enables us, on level snow of a suitable texture, to walk, or rather swing along, with an easy gliding motion; and that in descending hills the skier is principally concerned to keep on his feet, while the force of gravity does the rest. Owing to this unique capacity for gliding, ski are the footgear specially indicated for hill work when the ground is covered with snow. The fortunate circumstance that snow, except when in a very unfavourable condition, yields to moderate pressure, enables the expert ski-runner, by changes of the position of his feet and body', to guide himself, moderate his pace, or pull up altogether at will. On steep gradients, instead of running straight down in the direction of the slope, the can descend in a succession of sweeping curves. In fact, an expert man has his ski completely under control-only hard ice can defeat him. Even on so-called icy snow he will get along somehow.:

Needless to say, the beginner placed on a slope-especially when deprived of his pole-finds it by no means a simple matter even to remain standing on his ski. This introduces us to what -if we except the greater weight when being carried on the 
shoulder-is the only serious drawback to ski as compared with ordinary snow-shoes. Without preliminary practice they are worse than useless on the hillside; but the obvious moral is, that their use should be properly taught in peace time. To this question of training I will return later. I wish first to insist on the possibilities of ski in the hands-or; to be pedantically precise, perhaps we shoufd say on the feet-of a trained skirunner:

The first point is, that on level ground in good snow, and still more indisputably in hilly country, ski are incomparably superior to ordinary snow-shoes. . The next point is, that they are hardly, if at all, inferior even in bad snow and for uphill work. Nansen, in his Greenland expedition, took. Indian snowshoes, and also the smaller. Norwegian snow-racquets, called "truger." In very.loose deep snow, with the hill against them, he and his Norwegian companions seem to havefound the Indian snow-shoe preferable." (By "Indian:snow-shoe" is meant the form used in Canada.) But, notwithstanding, he sums up. emphatically in favour of ski. " Lest àny ireader," he says, " should be led to believe, by what I have here said about the state of the snow and the difficulties we met with, that our ski were of little or no use to us, I ought, perhaps, to state once and for all that they were an absolute necessity, that without their-help we should have advanced very little way, and even then died miserably or have been compelled to return. I have already said that ski are considerably better than Indian snowshoes, even for hauling purposes. They tire one less, both because they have not to be lifted, but merely driven forwards, and because the legs are kept no wider apart than in ordinary walking. For nineteen days continuously we used our ski, from early morning till late in the evening, and the distance we thus coyered was not much less than 240 miles."'

As regards terrain, almost the only conditions in which ski are relatively unsuitable are supplied by very dense forest, or undergrowth which is at once tall and close. Large boulders are, of course, unfavourable to ski-ing, but not so much so as appears at first sight t.. Unless they are strewn very thickly indeed, a way can generally be found through them when they cannot be avoided altogether.. 'The lower part of the Great Scheidegg - the pass leading from Meiringen to Grindel wald-looks in summer almost hopeless from the skier's point of view; but by mid-winter most of the moderate-sized boulders are covered, and one ski-es quite comfortably in and out among the larger blocks that still stand out.

Where there is'a likelihood of meeting with much ground of a very unfavourable description, it may be advisable to do as is sometimes done by military ski parties in Austria, and carry small racquets-which are very. light-to wear instead of ški when negotiating very bad bits.

1 "Crossing of Greenland;" I1.; 42-45.

Op. cit., II., $55-56$. 
To return to the question of snow. To the man who ski-es not, nor climbs, snow is soft white snow and nothing more. To the skier, even more than to the mountaineer, snow is of an infinite variety. In its ideal condition it almost seems to have been invented for the express purpose of meeting the skier's needs.. At its worst, it is never so bad as the language which it too often lets loose. It ought to be an article of faith in the ski-ing brotherhood that there is really no such thing as bad snow. Snow is always either good, better, or best. When snow ceases to be snow and becomes practically ice, it may be as well to carry the ski, and perhaps put on crampons;-but with this reservation we may assert that snow conditions which retard the skier increase in far greater proportion the difficulties of the man "on foot." Hence it is only an apparent paradox to say that the worse the snow is for ski-ing, the more useful do ski become. For the purposes of this lecture, therefore, we need not go into detail about peculiarities of snow. It will suffice to point out that some of the disagreeables of bad snow may be largely circumvented by quite simple means. : One of our worst troubles is that just after a snowfall, or when the temperature is close to the freezing-point, snow is apt to adhere in great masses to the bottom of the ski, adding a frightful weight thereto, and entirely putting an end to gliding. This "balling" of the snow may be prevented by " waxing" the ski, which operation, however, unless done very artfully, may make the ski so slippery that we can no longer get uphill at all. For uphill work a better preventive of balling is a detachable piece of sealskin applied to the under surface of the ski. This seems to have been the original purpose of the skin attachment as used by the Lapps and Finns, among whom the skin (of reindeer) was permanently fastened to the ski... But skins have the further advantage of enabling the skier to mount on slippery snow at a much greater angle than is possible on bare ski. The skin, being put on so that the hairs point rearwards, permits the ski to be driven forwards over the snow and, at the same time, checks the tendency to slide backwards. Many Austrian skiers keep their ski permanently well waxed, and wear sealskin the whole time except for the run down. In this way they aim, so to speak, at making the best of both worlds-uphill and downhill; but most skiers prefer the feel of the bare boards when ascending. on good snow, and on a steep descent in naturally fast snow. waxed ski are not always pure joy. It should be mentioned that there are other " artificial aids" besides skins; but unlike skins, they are no preventive against balling, and are not much used by practised skiers.

To complete our rapid survey of the seamy side of ski-ing, the dangers of ski-ing must next be mentioned; but this branch of the subject must be very briefly dealt with, especially as it is quite certain that the dangers of ski-ing, like those of riding, are not of a nature to weigh in the balance against its military. advantages. The chief kinds of danger for the skier are these: 
a. Personal injury from a severe fall; $b$. Breaking one's ski from the same caus - which may be a very serious matter on difficult ground, far fromi human aid; $c$. Frost-bite; $d$. Snowblindness; $e$. Crevasses; $f$. A valanches. Of these only the first two, namely, injuries to self and ski from falling, ought strictly to be ascribed to ski-ing, as such. The others are incidental to the climatic and geographical conditions under which ski-ing is, or may be, carried on, though, to be sure, the last named, i.e., the avalanche, is more serious for a man on ski than on foot. "But it is precisely injuries to self and ski that ought to be almost wholly ruled out of account when considering the use of ski in actual warfare, for we must assume that the side which contemplates using ski in winter warfare : will have trained skiers at its disposal. "Now, a good skier may be defined as one who never takes a considerable toss without deliberately courting it-for the satisfaction of his sporting instincts. The skier out for sport or practice will naturally take risks which, in a military capacity, he should carefully avoid.' For even a harmiess spill-. and we may admit that the most appalling-looking spills on snow are generally harmless-consumes more time than is gained by increased speed between spills; while a broken ski possibly; and a sprained ankle certainly, will put the soldier out of action altogether. The art of running safely; rather than the cult of mere speed, must therefore be the objective of military training on ski. Of course, this does not mean that straight, fast running is not to be practised at all; but only that in actual military exercises the pace at which slopes are taken must be commensurate with the skill of the runner, and that in such excrciscs a bạd fall should be regarded as a military blunder.

Dangers from falls being thus practically ruled out, we pass to those which are inherent in the nature of ski-ing grounds. Frost-bite is a real danger, particularly when, the skier is caught out in bad weather, but is one that may be minimised by the adoption of a suitable kit, especially as regards foot wear.

Snozy-blindness, again, is not likely to occur when the man is provided with proper snow spectacles, as worn by mountaineers. In the absence of such glasses, a pair of leather discs, each with a narrow slit for vision, are an efficient substitute. It is not always necessary to protect the eyes on snow in this way; but the skier should invariably take snow spectacles with him on any expedition.

Crevasses only occur on glaciers and above the summer snow line, i.c., in a region above that in which military operations may be expected to take place. The precautions to be adopted against them belong to mountainecring craft. ${ }^{1}$

iSce an article on "Mountaineering on Ski" in the Alpine Journal of 11 th August, Igo9 (pp. $56 \mathrm{I}-2$ ). The article as a whole is worth reading though on one or two points-notably as regards avalanches-the writer's views must be accepted with reserve. For sli mountaincering, see also the Annual of the recently founded Alpine Ski Club. 
Avalanches are by far the worst danger that the skier has to reclion with. If he intends to ski in steep mountain places, he must learn to treat avalanches with respect, or his career will be a short one. It may be assumed that large bodies of troops will never be deliberately. led over ground where avalanches are to the fore, and especially not under the meteorological conditions which render them probable; but the skier, in his capacity as scout, etc., may often have to venture on such places, and, of course, risks of this kind, that it would be folly for him to incur in peace time, may be quite legitimate in " the real thing." It is incumbent on the men who will act as leaders of ski partieseither in peace or war-to acquire mountaineering experience with a view to learning all they can about avalanches and mountain peculiarities in general. And even then accidents will occasionally happen: : In view of the avalanche danger in particular, it is imperative that the leader should really lead, and not be a slave to the "local knowledge" of a native guide (I am not speaking of guides in the mountaineer's sense of the word), for unless the inhabitants of a mountain district are accustomed to traversing their mountains in winter, they are apt to show an undue preference for the summer routes, which are by no means always the best or safest when under: snow:

The foregoing remarks on avalanches have perforce been of a very perfunctory nature. I have not even attempted to describe the different varieties of avalanche." For a ratlièr detailed (but still brief) and scientific treatment of the subject from the skier's point of view, I would refer you to TV. Paulcke's "Der Skilauf," the text-book of ski-ing officially approved for the German Army.

We may now pass to the question of speed. This is obviously a function involving, as important factors, not only the gradient and the man, but also the state of the snow. The worse the snow, the more nearly the value of ski is reduced to that of snow-shoes. In what follows, therefore, we must postulate the presence of snow in good ski-running order.

First as regards flat or moderately undulating country. Nansen asserts that a good man should accomplish sixty or seventy miles in a day, "if the conditions be moderately favourable." We learn from the same authority that the record long distance was made in 1884 by a Lapp, Lars 'Tuorda, thirty-seven' years of age, who, in a great race, the course being laid mainly over frozen lakes, covered 220 kilometres, or nearly ${ }_{13} 6 \frac{3}{4}$ English miles, in 21 hours 22 minutes, rests included. "Of the first six, five of whom were Lapps, the last came in 46 minutes after the first."'s

Of more immediate interest to us is the average speed to be expected of the "Continental "s runner. Lieutenant Czant,

I Published at Freiburg-i-Br.: Fr. "Wagner'sche Universitäts-Buchhandlung, th $^{\text {th }}$ Edition, 1908 .

2 "Crossing of Greenland," I., 109-1 1o.

3 In ski-ing parlance, the "Continent" excludes Scandinavia. 
of the Austrian Army, in his very useful book, "MilitärGebirgsdienst im Winter,"1 says that on fairly level ground detachments of skiers, in full marching order, will normally march at a rate of from 5 to 8 kilometres (say, from $3 \frac{1}{1}$ to 5 miles) an hour. Small patrols, or orderlies, will undoubtedly move much more rapidly, though hardly at double the rate, as Lieutenant Czant claims-except for short distances.

In mountainous country, vertical rather than horizontal distance is the thing to be considered. It is usually held that it takes from one-quarter to one-third more time to accomplish a given ascent on ski than it does on foot when the ground is freed from snow. But in my own experience, the times under summer and winter conditions differ but little; provided that no attempt is made to press the pace in either case. The rate may be taken for the average man as one hour for every 1,000 feet of vertical distance in the ascent, including short halts, but not any prolonged rest for meals, etc. This seems to accord, too, with the experience of Captain C. Hordern, R.E., as given in an excellent paper-to which I am under considerable obligations-on "The Uses and Possibilities of Ski." A man in a hurry, however, to "do" his pass or peak in the shortest possible time-which is the normal state of mind of the youthful and inexperienced mountaineer-will make better time under summer than winter conditions. The habit of cramming on pace uphill, except where special circumstances require the effort, is to be discouraged on many grounds. It puts a tremendous strain on the man, especially if heavy laden, and throws him into a violent perspiration, so that when a halt is called he will probably be quickly chilled to the bone. A good rule is never to go so fast as to cease to breathe through the nose instead of through the mouth. A further objection to undue hurry in the ascent is that in subsequently descending the man will not be nearly so steady on his feet.

In descending, the limit of speed is that of a falling body, and this velocity, as Nansen says, may be sensibly approached by a good ski-runner-though it is difficult to maintain the highest rate of speed for any length of time. If the skier does not check himself, : probably something else will-and more effectually, But-racing apart-I think that for the ordinary "Continental". runner an average rate of 1,000 feet vertical interval per ten minutes may be considered quite good. $\quad$ This will include short halts to reconnoitre the ground, and to make sure that one's companions are still all there. Whenever possible, we "may. here observe, skiers should run in groups of three or four. Eight is perhaps the largest ' number that can be ! kept well together under one leader in a long descent. For each indi-

1 Vienna and Leipzig, 1907. Translated into French by H. A. Tanner (Captain in the Swiss Army), under the title "Alpinisme et service militaire d'hiver ": (Paris and Iausanne). 
vidual skier must be left plenty of room, it being practically impossible for anyone else to foresee where the man may find it necessary to make a turn. If the members of the party are running in a bunch, collisions are inevitable.

Having now, it is to be hoped, grasped the general nature of ski-ing as a means of locomotion, we shall probably be prepared to admit that, given thie conditions under which ski come into play, 'their military value follows as a matter of course. This value has indeed already been put to a practical test. In Scandinavia, ever since the year 1200 , if not earlier, shi have been employed in winter warfare. In the war between Norway and Sweden in 1808 the Norwegian ski contingent was 2,000 strong. The skiers proved, as always, of the greatest service both for fighting purposes and for reconnaissance. On the Swedish side, too, they demonstrated their utility in rearguard actions.

Instances might be : multiplied where commanders have suffered owing to their being unprovided with iskiers. It has been pointed out; e.g., that the disaster at the Bérésina would probably not have occurred if! Napoleon had had at his disposal-skiers for reconnoitring and despatch-carrying, : and - to cover the actual crossing.

As an instance where our own troops were seriously handicapped for lack of any kind of snow-shoe, I think the crossing of the Shandur Pass by Colonel Kelly's force in the Relief of Chitral may suffice. $i$ The crossing of this pass without special appliances was indeed a wonderful performance, but it tried to the utmost the splendid men who executed it.

"Captain Borrodaile's men found the task of crossing the pass just heart-breaking; every few steps they would sink in through the snow, although some sort of a track had been beaten out by the levies going on in front. . At times they would fall in almost up to their armpits, so that they had to be pulled out by their comrades. This was fearfully trying to men loaded as they uere, to men, too, who had passed an almost sleepless night, and started for this, the crisis of the enterprise, thoroughly exhausted:?

"By the time the party had reached the middle of the pass men were falling out in twos and threes, sitting down in the snow as if they were on the point of giving up the struggle. ..... The snow was from three to five feet deep, and quite eighteen inches of it was soft and fresh; at the same time the sun was pouring down upon the men. . . . So exhausted were the men that it seemed at one time to the British officers

1 For'a brief summary of the Scandinavian wars, in which ski have been used, see Paulcke's " Der Skilauf," pp. 136-137.

2" Each Sepoy was allowed fifteen pounds of baggage; and he carried a greatcoat and eighty rounds of ammunition, and wore a short 'poshtin' (sheepskin coat)," Op. cit., p. Izo.

'They had been obliged to bivouac on the snow the previous night at Langar. 
that it would be necessary to spend another night in the snow, but at about $5 \cdot 30$ the advance guard came to the end of the flat part of the top of the pass, and the descent was at last commenced."'s

"In the evening, on arrival at Laspur, Surgeon-Captain Browning Smith made an examination of the men who had crossed the pass, and found 25 cases of frost-bite, and 30 of snow-blindness. These were fortunately not severe, but it was evident that even one more day's work such as these troops had had to undergo would have quite incapacitated the force."?

On the next page the authors speak of the troops having "behind them this terrible pass, practically cutting off their retreat."

This experiment in doing without snow-shoes for snow work can hardly be regarded as justifying persistence - in .. the old methods; for consider the geographical facts. The Shandur Pass is described by Lieutenant Beynon in his book "With Kelly to Chitral" as " a very gradual slope-so gradual, in fact, that it is difficult to say when the top of the pass is reached. This slope .... is some five miles long, and 12,330 feet above mean sea-level; absolutely bare of trees, and with two fair-sized lakes upon its surface. . . . The lakes were frozen over, and the valley was one shept of spotless snow, lying dazzling in the sunshine. The distance from Langar on the east to the village of Laspur on the west of the pass is not more than 10 miles, yet Borrodaile's party, leaving Langar at daybreak, did not reach Laspur till 7 p.m."

It seems clear that the snow was in thoroughly bad condition, but the Younghusbands' narrative would appear to bear out the contention that snow conditions which make ski-ing unṕleäsant may render ordinary marching on foot practically impossible. In this particular case the impossible was accomplished ;but we may with some confidence assert that the Shandur Pass woinld have been mere child's play to these same men if they had been mounted on skin-clad ski, or even racquets. Moreover, it can hardly be doubted that a detachment on ski, starting from Langar at the same time would have been well over the pass before the surface had been reduced to its worst condition by the action of the hot sun on the newly fallen snow. It also seems' reasonable to surmise that, starting from Teeru on the previous day, they could have accomplished the entire traverse to Laspur in one stretcli, without having to bivouac on the snow, as Captain 'Borrodaile's men had to do." The task of getting over the two mountain "guns, which had temporarily to be left behind, would also have been enormously facilitated if only the

1 "The Relief of "Chitral," by Captain C. J. and Captain: F. E. Younghusband, pp. $145-147$.

2 Op. cit., p. 147. The force numbered 290 men:

3 OP. cit., p. 40. 
gun detachment had been on racquets. Again, with suitable equipment it would not have been necessary to divide the force, as was actually done, Captain Borrodaile's detachment being sent on in advance as a sort of forlorn hope. And finally, with proper equipment there would have been no necessity to give up a day to recuperating from the effects of the march. In 1895 , it is true, the use of ski and racquets had not yet been all but universally adopted by the military Powers, so that we could not at that date be accused of being behind the times; but in the future we shall not be able to plead any such excuse.

This historical event of the crossing of the Shandur Pass has been cited primarily to illustrate the need of snow-shoes of some kind or other when military operations have to be carried out in deep snow. There is no intention of claiming that under such conditions the bulk of the troops should be on ski in preference to racquets. On the contrary, ski and racquets should probably always be used in conjunction, as is actually the practice in the Austrian and other Armies. We have seen that it is more particularly for mountain warfare in winter that ski will be really invaluable. But we have also seen that the very superiority of ski as an instrument of locomotion over all other forms of snow-shoe has as its corollary the need for allowing the greatest possible freedom of movement to the individual skier when running downhill. In descending long slopes, and still more in descending through a wood, no large body of skiersunless : of the "stamp" that we find in Norway-can be expected to combine avoidance of collisions with the maintenance of some degree of cohesion. For these reasons the chief military use of ski will be for purposes of scouting, despatch bearing, arid cognate functions. In a word, the rôle of the skisoldier will be to replace the mounted soldier under conditions which render the latter partly or wholly immobile. The very conditions, "which even in flat country confine cavalry and ordinary infantry to beaten tracks, open up the whole countryside to the skier. Just às the "estranging" sea of the poets' fancy has been converted by hard-headed men of action into a great highway of communication, so the "barriers" of snow are seen by the skier to have been made only, to be trampled on.

Since in mountainous country a very small body of men will often suffice to hold large bodies of the enemy in check, the skiers, even though few in number, will often be able to seize and hold a pass in advance of the main body. . Obviously, too, they will be able to render great services in securing flanks and rear, especially (in European warfare) against harassing attacks by the enemy's skiers.

The limitation set by the preceding considerations on the number of skiers required with a given force furnishes a sufficient answer to the objections sometimes brought against the military use of ski on the score both of expense and of the difficulty in training any very large number of men drawn from populations unaccustomed to the unse of ski in civil life: Similarly we 
may treat as irrelevant the objection that a whole battalion on ski would occupy at least three times its normal length in column of route. None of these objections apply to the use of racquets : these are cheap and durable; their use can be learnt in a few minutes;' and they do not entail any lengthening out of a column. The point is, that with infantry on racquets there should be a complement of skiers, for the performance of functions that under normal conditions, and in flat country, would fall chiefly to the cavalry or mounted infantry:

More serious is the objection that ski are a greater encumbrance than racquets. This, of course, applies to ski only when they have to be carried by the soldier in addition to his rifle, i.e., when they are not in actual use. In such case the soldier might be relieved of his ski, since a quantity. of ski can easily be taken on one sledge. And conversely, when-as will probably most often be the case - the skier will be required for purposes of observation and communication, rather than as a rifleman, it seems permissible to cut down his fighting equipment in order to secure the maximum of mobility.

The foregoing general principles as to the tactical employment of ski-soldiers underlie the training which they receive in foreign armies.: Broadly speaking, in those Continental infantry. regiments that are specially prepared for mountain warfare, from two to four men per company are annually trained on ski, these men being carefully selected for physique and intelligence. It is not intended, I believe, to take them away from their regiments in war time; the regiments will simply furnish the details as required for special services. .

Switzerland is not really an exception, for though the infantry are not underarms in the winter, ski-ing has of late years been taken up by the mountain-folk to such an extent that the Government can count upon having in time of war as many skilled skiers among the rank and file as they will require. But voluntary ski-courses were officially instituted in Igo7 for the instruction of officers and non-commissioned officers, and are well attended. Also, the men on permanent duty in the St. Gotthard Forts are on iski for nearly half the year. Indian snow-shoes and racquets are also served out to these troops.

The two countries whose experience will probably be of most use to us if we ever make up our minds to try this new thing - new to us, I mean-are Norway and Austria. The Norwegians will probably always hold the field as exponents of the art of ski-ing, and it is from them that we shall best get hints as to equipment, methods of camping in snow, utilisation of horse-traction where possible-and in short all the divers tricks of the trade. But the country in which the Norwegian military ski-exercises are usually carried out is not of a truly mountainous description, as is the Tyrol, and indeed the greater part of Austria proper. In Austria mountaineering is the most popular sport, and this has. paved the way for the development of ski-mountaineering, both in civil and military life." In fact, the Austrians may be said 
to have made quite a speciality of ski-ing on ground that is too steep for comfort-redressing the balance by the excellence of their mountain "huts." The Norwegian on a steep slope is still better than anyone else in the same predicament, but he seems to prefer slopes where he can (apparently) throw prudence to the winds.

Again, there is one thing-most necessary to us-in which the Norwegians have practically no experience, and that is the instruction of grown men who have never learnt to ski. It is therefore to other countries that we must turn to see what can be made of the raw material for military purposes, and what are the best methods of training.

Very few men who have put off learning to ski till they have out-grown petticoats will attain the highest standard of excellence. But, on the other hand, there does not seem to be any other first-rate sport in which a learner of mature age can so rapidly attain a fair degree of proficiency - a degree amply sufficient for all ordinary military purposes. Up to the age of 55 at least men can learn to ski well enough to qualify themselves for long expeditions, and men under 30 should reach that level with very few days' assiduous practice under a good instructor. Taking classes of about twenty men, Austrian experience shows they can be turned into ski-soldiers in a fortnight.

Lieutenant Czant, in the book I have already referred to, has drawn up the following programme for a fortnight's recruit instruction in the field. . (He postulates previous "theoretical" instruction in the barrack-room.)

First six days, during which light equipment only is worn: beginning on the flat, the men are taught how to stand, walk, and turn; next, on slopes of from $15^{\circ}$ to $20^{\circ}$, standing, walking, turning [standing, or kick-turn], gliding, braking, getting up after falls; next, on slopes up to $35^{\circ}$, the same exercises, with practice in descending a hill obliquely, and turning while gliding.

Seventh to tenth days: same exercises as before, on slopes up to $45^{\circ}$.

Eleventh day: the same, on slopes up to $50^{\circ}$, if the state of the snow permits.

Trvelfth day: same exercises, combined with practice in taking cover and firing on ski-standing, kneeling, and lying.

Thirteenth and fourteenth days: marching at the double, with perhaps a night exercise.

Finally, there remains the question : What facilities are there for training our own troops on ski? Of the Himalayas, as I remarked at the outset, I cannot speak from personal experience; but it appears from a letter written by an officer and

1 There is not as yet any official manual of ski instruction in the Austrian Army.

VOL. LIVे. 
published in the "Year-book of the Ski Club of Great Britain" for 1905 , that in parts of the range, at any rate (i.e., in Kashmir), good ski-ing may be had up to the beginning of June at heights of ro,000 feet and upwards. ${ }^{1}$

Two years ago the telegraph department in Kashmir laid in some pairs of ski with a view to utilising them in keeping the telegraph line open between Srinagar and Gilgit during the winter. It must be confessed that the department has been extremely reticent as to the results of this experiment; Mr. E. C. Richardson (who was instrumental in procuring the ski) tells me he has received no information relating thereto. But as the men employed in the work of repairing the line are coolies, the department was not, I gather, over-sanguine at the outset. The coolie; I am given to understand, is not exactly the right sort of material out of which to fashion a dashing ski-runner. He would probably be averse to exposing himself to unfamiliar risks on so new-fangled a contrivance as ski; he would most likely prefer to go on being killed by avalanches in the way he has grown accustomed to. As far as one can judge from a distance, it certainly appears as if, with the right sort of men (say, with Gurkhas), and with capable instructors, a great deal could be done in the ski-ing line out there.

It is undoubtedly in connection with the Indian Army that ski-ing has most importance for us. But there are other contingencies that, perhaps, ought not to be overlooked altogether, and in view of these it may be pointed out that it is quite possible to learn ski-ing in the British Isles. In the Scottish Highlands, in particular, ski-ing seems to have quite caught on. There is even a flourishing "Scottish Ski Club," numbering over Io members. ${ }^{3}$ From our present point of view special interest attaches to the experiment of Brigadier-General Malcolm; D.S.O., Commanding the Cameron and Seaforth Brigade of Territorials, who has distributed several pairs of ski among some of his companions in the Grampians, and in the two winters before last instructed a good many of the men in their use." He informs me that "the young fellows took to it keenly," and they seem to have made good progress. May we hope that the matter will not be allowed to rest there? What is possible for Territorials should surely be possible for Regulars.

Captain J. B. Wrougniton (2nd Battalion Royal Sussex Regiment) :-I have had cight years' experience of ski-running, and have always contended that ski-ing is of interest to the British Army, and that is my excuse

"per contra, see the "Year Book" for I90\$, pp. 49-50-Letter to the Editor from Captain C. Kirkpatrick, The Guides, on "Ski-ing in India." The Editor appends some comments.

2 On the passes in question 200 lives were lost by avalanches in 15 years.

"See "Year-Book of the Ski Club of Great Britain" for 1908, p. 6.

\& Op. cit., p. 14 . 
for making a few-observations on the excellent lecture we have listened to this afternoon. The lecturer mentioned the advantages of ski-ing as being "sufficiently great to free us from the temptation of exaggerating them." This reminds me of a statement I once heard made when I was urging the utility of ski for military purposes. It was gravely suggested that a large body of soldiers on ski might have considerable effect on the tactical situation if they could charge down on the enemy's flank at the rate of 50 miles an hour. Here indeed is a case of preserve us from our friends, for I am sure no one will expect skiers to practise " shock tactics." It seems clear that the real utility of ski will be found, as suggrested by the lecturer, in carrying out the duties of scouting, dispatch riding, and cognate functions. After giving us the historical event of the crossing of the Shandur in 1895, Captain Knox mentions that "at that date" ski had not been universally adopted by the military powers and so "we could not be accused of being behind the times." I can give an instance of much more recent date-1907 (by which time the use of ski was recognised by all those armics the lecturer has mentioned). In October of 1907 when the troops from Chitral had to cross the Lowardi Pass, thirteen lives were lost. Here, as one writer stated, it was necessary to push on before the pass became blocked with snow. Had the garrison been skiers they would have weloomed the advent of snow; "the more snow the better" is what all ski-runners will say. I have noticed that the ski-tracks (spoor) of even a small party quickly harden, and I have myself walked along such tracks with ease, when to move off them in the smallest degree resulted in my sinking up to the knees in snow. I should be glad to hear the lecturer's views as to what extent a large ski party would harden the snow sufficiently to allow the passage of heavily laden pack animals. Captain Knox has mentioned the fortnight's training of the Austrian soldier, and I can bear testimony to the thoroughness of this instruction. Before the end of the fortnight most of the class can make the "telemark" swings to the right and left, and make wonderful good practice running down hill over difficult ground. The practice in the Austrian army of using ski in conjunction with " rackets" mentioned by the lecturer, is one which is not universal, for though I have secn men of the Kaiser Jäger Regiment from Innsbruck on ski almost daily during my winter leave this last two years, I have never seen a pair of snow shoes used. If "rackets" have been issued to this regiment they must be kept, probably, well oiled in the mobilisation store. A very good place, too, for I consider the long ski must always be infinitely preferable to the foot-slogging snow shoe.:

Lieut.-Gencral H. D. Hutchisson, C.S.I.:-I cannot speak with authority on this matter because I have no practical knowledge of ski-ing; but in speaking of the training of British soldiers for duties on snow-clad frontiers the lecturer alluded particularly to the frontiers of India, and to the value to Indian troops of knowing how to use the ski. It is quite true that India has snow-clad frontiers, but they are very remote indeed from any cantonments where British or Indian troops are stationed. Except, perhaps, in the. Valley of Kashmir, during the winter months it would be practically impossible to provide opportunities for the training of troops in India. And even if trained, the occasions when the ski could be used by troops of the Indian army: would be very rare. I have been twice engaged in operations in snowy countries: once in the Valley of Chitral, where we spent a year, and once with the 32 nd Pioneers for 
a whole year on the Silkkin Frontier, where we spent the winter at a height of 12,600 feet above the sca. There possibly if we had possessed skis, and known how to use them, they might have been useful; but unless the troops had been trained beforehand in time of peace, of course opportunities of this kind could not be made use of, and it is practically certain that the training could not be arranged. There is only one other remark I wish to make, and that refers to snow blindness. Anybody who has been much in snow knows how easy it is and how distressing to suffer from snow blindness. In Sikkim we had many severe cases of snow blindness. Of course tinted spectacles or goggles ought always to be provided and worn when you are morking or travelling in snow, but you have not always got them. We found out by experience a very simple substitute worth knowing if you happen to be in snow without spectacles. It is just charooal paste mixed with oil and smeared on the check bones below the eyes, and on the sides of the nose. This simple precaution is an efficient protection against snow blindness. A regiment on parade decorated in this way, especially when the men enter into the spirit of the thing and add fancy moustaches, etc., presents a remarkable appearance; but $I$ have seen this expedient adopted in snowy regions, and I can vouch for its being effective.

Captain H. V. KNox :-I have really nothing to say in reply, but I should just like to thank Captain Wroughton, whom I have not seen before; but whom I have often wanted to meet. I myself rather doubt whether ski can be used to beat down snow sufficiently to allow infantry to pass over it afterwards. The extent to which snow beaten down by snow shoes allows infantry afterwards to walk upon it is very largely a matter of how much the man making the tracks has sunk through. Racquets would in any case be better than ski to enable men to walk in the track afterwards. A man on racquets does a little work in beating down soft snow for men behind him, since he sinks through the snow a little. In Austria experiments are occasionally made, but not often, with racquets, and even ten or a dozen men on racquets do not beat the snow sufficiently for men to follow on afterwards without sinking through still further. I hope in a year or so to make some experiments myself in that matter.

The Chalrain (Brig.-General H. H. IVilson):-It lies with me now to sum up. To me this ski-ing, which I have been at now for some years, has a sort of Pickwickian fiavour. You remember how good Mr. Pickwick: was when he went sliding, and you can imagine how good he would be on ski. You can imagine Mr. Winkle on the ski. Imagine Mr. Micawber, who was always waiting for something to "turn up," if he had put on a pair of ski and put another pair on Mrs. Micawber, they would not have had to wait more than a minute or two, for something would infallibly have "turned up." My own experience is this, that you can leave London in snow and sleet and fog at half-past two on one day and be in the most glorious sunshine the following afternoon at tea time, on ski, or on your head, or any other part of your person you preferl That can be done at any time you like in January, February, or March. With regard to the military value of the ski, I quite agree with the lecturer; it seems to me its uses will be almost entirely confined to scouting. $\Lambda$ few scouts might certainly work the ski to great advantage. I also agree with something the lecturer said in the very opening sentences of his lecture, where he stated that it was neither " safe nor dignificd to assume that the interests of the British soldier in future 
European conflicts must necessarily be of a purely academic character." 1 should like to add to that "And confined to this country," as so many people seem to suppose will be the case. We have fought in Canada before; we have fought in the Valley of the Danube before; we have fought in the I.ow Countries and in Spain before; and for the life of me I cannot see why we should not fight there again. In those countries there is no doubt you can do some shi-ing. Last year I was in the Lisaine Country, where General Bourbaki carried out his fateful compaign in a bitter cold and snowy winter, and undoubtedly we could work the ski well all over that country, so that from that point of view I think it is well worth our while practising. We can practise a little in this country, we can practise a little in Canada, and we can practise a little no doubt in the North-IVest. Those are the only remarks I have to make, except that I am sure you will join with me in thanking the lecturer for bringing forward such an interesting topic. 